\title{
Impact of Exchange Rate on Foreign Direct Investment in Pakistan
}

\author{
Muhammad Bilawal, Muhammad Ibrahim*, Amjad Abbas, Muhammad Shuaib, Mansoor Ahmed, \\ Iltaf Hussain, Tehreem Fatima
}

Bahaudin Zikria University, Bahadur Sub Campus, Layyah, Pakistan

*Corresponding Author:ibrahimkhanleghari@yahoo.com

Copyright $(2014$ Horizon Research Publishing All rights reserved.

\begin{abstract}
Exchange rates have main role that affect the macroeconomics performance of any leading country. The objective of this research was to investigate whether uncertainty or fluctuations in exchange rate affects the macroeconomic in Pakistan. This Study was based on secondary and time series data. For this purpose 32 years old data of Exchange rate and FDI for the period of 1982 to 2013 was used and was collected from the website of State Bank of Pakistan. The tests of Correlation and regression analysis were applied through SPSS software to check the relationship between Exchange rate and FDI. The correlation results showed that there is positive significant relationship between Exchange rate and Foreign Direct Investment while in regression analysis the value of $\mathrm{R}$-square $=0.679$ which shows that the independent variable Exchange has $67 \%$ impact on dependent variable Foreign Direct Investment and research model is accurate. This research will help the mangers, related organization and future researchers to make or revise the further economic decisions.
\end{abstract}

Keywords Exchange Rate, Foreign Direct Investment

\section{Introduction}

FDI stands for Foreign Direct Investment, a component of a country's national financial accounts. Foreign direct investment is investment of foreign assets into domestic structures, equipments, and organizations. It does not include foreign investment into the stock markets. Foreign direct investment is thought to be more useful to a country than investments in the equity of its companies because equity investments are potentially "hot money" which can leave at the first sign of trouble, whereas FDI is durable and generally useful whether things go well or badly.

(Khan et al. 2012) studied that exchange rate is a most important factor in an open economy it has direct effect on the macroeconomics factors like FDI and GDP. Economics, investor and Policy maker focused on the exchange rate of country and then make investment their money in that focused country. They have believed that increase in exchange rate creates competitive advantages in international trade. By increasing exchange rate of a country the domestic export goods become cheaper and it also increases the demand of export, it means international demand of goods will increase and import will be decreased. It impacts on FDI, all of these effects ultimately on GDP of the country.

(Javed and Farooq, 2009) investigated that exchange rate means how the unit of domestic currency can be change with the other nations currency unit. Simply it is change of one country currency into the other country currency. The demand and supply of currency actually are the main element of exchange rate instability. Exchange rate instability directly affects the decision makers to decide that how much import and export is favorably. It also tells that how much things should be manufactured, import, export, money taken reserve and balance of payment. Exchange rate also impacts on the prices of export, import and balance of payment. Exchange rate works as a great opportunity for domestic investor to earn high profit by investing in foreign currency. The investors and traders like that system where there is very small inconsistency difference, between actual and expected value of exchange rate. The instability in exchange rate is source of higher profit; it is the perception of one school of thought.

(Takagi and Shi, 2011) investigated that there are two different school of thoughts on export, one is classical and other is neoclassical, they believe that the free involvement of international market has a great role for the growth of any country and it is the solution of the crises of the countries. Both theories believe that by using their resources country should produce that product which they can produce efficiently by gaining competitive edge, as the world have become global village. The demand of the product will be increased when a country will produce their product inexpensive, so in all over the world due to global village, money will be redistribute as export will be increase. (Mustafa and Nishat, 2004) studied that when exchange rate 
moves from fixed to flexible exchange rate it means we are facing instability in exchange rate. The different theories say when the instability in exchange rate increases it directly impacts on the export trade, export trade decreases due to uncertainty in future profit. In short term by managing the receipt and payment efficiently companies can reduce the uncertainties in trade. Due to instability in exchange rate there is big risk for investor, in this way trade profit reduce instability in exchange rate and adverse relationship with demand of export. Pakistani export is based on volatility of exchange rate. Pakistan has option of market United State and United Kingdom over Japan and West Germany.

(Rehman et al. 2012) proved that the benefits of exchange rate depreciation in Pakistani rupee are decreasing up to 30 years as compare to foreign currency. The floating exchange rates depend upon market situation. It's done with the hope of balance of trade. Currency value can be explained two ways. The First one is when the currency is devaluated, the domestic goods become cheaper and the foreign goods becomes expensive the demand of local products increases, and then the foreign country definitely improves trade balance and promotes local goods. The second one is real value of cash reduce due to devaluation of money. The foreign currency export become cheaper and import become expensive when the value of local currency and goods goes down.

Number of theoretical models has been emerged in the literature regarding the volatility of exchange rates. These models give the direction how the volatility in exchange rates affects the trade flows positively or negatively, it depends upon various factors, including assumptions about risk attitudes. The most common explanations are the transaction cost, for the negative relationship between exchange rate volatility and trade comes. The cost of converting a currency to other and the risk associated with potential changes in exchange rates have a dampening effect on trade flows. Lot of theories has analyzed the impact response of commercial enterprises to exchange rate uncertainty, by focusing on their degree of risk aversion.

(Ling et al. 2008; Ibrahim et al. 2014) the different levels of economic development; the depreciation of the currency has a significant impact on the trade balance. If we total the value of export demand and import, one of the most significant effect, shows that the depreciation of the actual increase, leads the trade balance in the long run be more than one, it is the Marshall Lerner condition. To improve the trade balance, there are two different ways. The first way, it increases the volume of exports. The currency depreciation makes it clear inexpensive domestic product compared to foreign goods in order to create competitiveness of export. The second shows that, import volume is reduced import as is the relatively expensive or, the amount of response may not be provided in the initial depreciation of import and export. Due this, the balance of trade can increase in the value of imports and decrease in the value of exports, after some time the deterioration of the first improved.

As it was studied by (Mustafa and Nishat, 2004) found that the high degree of uncertainty and volatility of exchange rate movements observed in Pakistan, is a main concern of policy makers and researchers to find the extent of the impact of these movements on the volume of trade of Pakistan. It is known that the higher the volatility of the exchange rate minimizes the trade by creating uncertainty about future profits from exports. These uncertainties need coverage in the short term and influence the investment decision of the company in the long term.

It is a big opportunity by the volatility of exchange rates for investors, to invest in foreign currency (dollars) to obtain higher yields and leading to strong the dollar against the currency of the home. Which directly affects the price of exports and imports? Averter risk investors and traders still prefer the system, where the variance of the difference between the expected exchange rate and actual value is minimized, while trader's lover risk and investors prefer to volatile exchange rates. In this way they can maximize their profits due to the high risk premium. The uncertainty of exchange rates may have a positive impact on imports and exports and negative for trader's lover risk and vice versa for risk averter traders (Payaslioglu, C. \& Polit, B. 2013).

(Takatoshi, 2007) studied that changes in exchange rates work like shocks to the economy. If it is established, that a natural response to the shock of exchange rate can not jeopardize the inflation targeting, then pursue both objectives with one instrument cannot be so bad. It tends to have the effect of lowering the rate of inflation through two channels, lowering the cost of imports and curb output by discouraging exports, when the exchange rate appreciates. The appropriate response in such circumstance lowers interest rates to stimulate the economy, unless the inflation rate is too high to begin with.

(Huchet and Korinek, 2011) searched that the role of FDI for growth in developing countries is very important. Foreign investors are motivated to invest in the host country, if the prospect of making long-term profits by contributing area that host country of production are very obvious. The foreign direct investment not only plays its vital role to capital formation in developing countries, but it is a source of technology transfer and innovative skills from developed to developing countries. For the development of the least developed countries, these countries offer incentives to foreign investors in order to attract more FDI.

Pakistan has also taken initiatives to attract foreign investors to invest here, during the last decade. For these initiatives reforms in the macro-economic environment are essentials. From 2005 to 2006 the Foreign Direct Investment inflows in Pakistan are more than $\$ 3$ billion in the first ten months of the year, which is the highest figure of the history of Pakistan. The export promotion in developing East Asia and the countries of South-East Asia, it is hard to ignore the role of foreign direct investment (FDI). The most IDE undertakes multinational companies (MNCs) to network, market relations worldwide and up to date market information are well established. The exports of developing countries are promoted or not by FDI, are controversial 
debate in the literature and it depends on the purpose of these investment flows. If the purpose of FDI is to get benefit from the comparative advantage that the domestic economy has on other nations while FDI can help to promote exports. FDI also depends on the political system of the country. The trade policy can encourage FDI to capture the domestic market and facilitate national population; in countries following research inward (Hassan and Mahmood, 2013).

Our main purpose of conducting this research is to investigate the impact exchange rate on FDI in Pakistan. By collecting data on both variable Exchange rate and FDI, we want to show how these variables affecting each other. The research which we are conducting is practically implemented because it's related with Pakistani economy. It's useful for financer and Foreign Investor to know the economy of Pakistan as well as how many benefits he can get from exchange rate how the worth of their asset will be increase due to impact of exchange rate on their assets, for performing their practical operations like investment. So, this research will be helpful for Investor how to maximize the profit of firm and compete with their competitors. In this way foreign investor can get advance knowledge through research.

\section{Objective}

The main purpose of conducting this research is to investigate the impact exchange rate on FDI in Pakistan. By collecting data on both variable Exchange rate and FDI, we want to show how these variables affecting each other.

\subsection{Specific Aim}

The specific aim of this research was to investigate the effect of exchange rate on foreign direct investment.

\section{Literature Review}

As the International Monetary Fund (IMF) define that "Foreign direct investment (FDI) means an investment made to acquire long-term interest in enterprises operating outside of the economy of the investor." The FDI is very important source of external financing means, in which the countries with limited amounts of capital can obtain financing beyond national borders countries. FDI rich is an important source of financing for development and contributes to productivity gains providing, better technology, management expertise, new investment and export markets. Lack of investment in developing countries and given the resource constraints, it has been increasingly on market forces and the private sector as the engine of economic growth. According to neoclassical growth model, FDI promotes economic growth by increasing the efficiency and volume of investment. Therefore, all countries, least developed countries and particular developing countries seek to attract foreign direct investment for all the benefits it brings with it in the host economy. FDI, not only complete national investment resources but also works as a source of foreign currency and relax the balance of payment constraints on growth. Most countries have made major changes in national policies to attract FDI, in order to considering the economic benefits and importance of FDI to promote economic growth.

There is vital role of FDI in the economic growth of the host country when accompanied by greater openness and sound domestic policies. Real exchange rate and FDI are bi-directional relationship. During the decade since 1988, it is said that Pakistan's economy is characterized by an increase in growth rate of GDP, an increase in FDI a sharp increase in the opening leading to a worsening balance of payments position continued high levels of poverty, unemployment and lower import duties. Pakistan has experienced an increase in wages in the informal and salaries sector production sector until 1990, due to globalization. The literacy rate and number of universities has increased. The progress in social is the key role of trade and investment, liberalization should be recognized in raise living standards and the creation of new business opportunities.

In this research the foreign direct investment in Pakistan is taken as the dependent variable. The IDE includes imports of goods, purchases of fixed capital goods and exchange for other corporate transactions. The investors are reluctant to invest in an economy where economic bases are weak. The rate of real exchange rate will measure the effect of local exchange rate on FDI inflows and will analyze if the devaluation of local Rs has a positive impact on FDI or not?

FDI investment defines the movement of capital which implies control in the country and owner. FDI is the main driver of the globalization of the world economy and it is also essential economic development of the home country. (Tataoqlu and Erdal, 2002) proposed that " FDI flows helps to build strong economic ties between developing and industrialized countries.

While some economists called attention to the possible costs of FDI for the host country and most literatures discussed the likely benefits of those that cannot occur in all cases any more than they do occur in the same order of magnitude for both developed economies and developing economies. These discussions focus on the benefits of FDI flows to developing countries, so that FDI leads to economic development through the creation of GDP in the host country, new employment opportunities are increased, exports, wages, and tax revenues are also increased.

Many economists believe that the technical and managerial skills are scarce in developing countries. In this case, a crucial bottleneck restriction is broken when foreign capital brings essential skills of human capital in the form of technicians and managers. The new technologies are invested in the host country can increase the production potential of the recipient country and also have an impact on the economy. Simply, FDI is considered as a vital source of inputs in many countries, especially in developing countries in the shape of contributions in the economic growth of a country. In this sense, given the economic consequences of FDI, it is not afraid that all over the world looking for a way 
to expose and attract new policies that strongly appeal to more investors. While some countries have been so successful in attracting FDI inward at a high rate and LDCs (least developed countries) have been suffering from low amount of between them for years. However, in an analysis of global trends in the world, it is very clear that the volume of FDI flows to developing countries increased remarkably in the 1990s and especially after 1995 .

The related question to ask is differentiated as, what is a main reason behind foreign investors looking for a country to make investment and why some countries have high levels of FDI, while others do not. With the intention of returning, foreign investors are in a foreign market. But, they are exposed to different lot of types of risks as well. These risks involve some sort of factors such as the exchange rate risk, legal risk, political risk, etc. As long as investors are optimistic about the situation in a foreign market, invest their money and reinvest their earnings in this market. Therefore, as well as economic, such as market size, political factors, inflation, and social risk, and interest rate and so on, the effect of exchange rate volatility and FDI become an important issue in the literature as key determinants of FDI flows.

There are two arguments, which include the argument of production flexibility and argument of risk aversion. According to first argument there is a direct relationship between the volatility of FDI and exchange rates, the second argument defines that there is an inverse relationship between these variables respectively. When facing the other side of the coin, the FDI host country can also cause an appreciation of the exchange rate with the outputs or inputs with damping (Sattar and Rehman, 2012).

According to (Bleaney and Greenaway, 2001) the countries using currency attempt to influence FDI inflows from countries using the weak currency, the cash flows leads to the presence of FDI. The modern literature about the concept of the effect of exchange rate changes on FDI flows began with assumption of perfect capital mobility in the world after 1990. There are also several hypotheses which explain how FDI flow reacts to changes in the level of exchange rate. One of them is the wealth position assumption. For this hypothesis, FDI closely looked on the foreign exchange market by the impact of changes in the level of the exchange rate on the relative wealth of the two countries of destination and origin. According to (Froot and Stein, 1991) the role of exchange rate in the amount of FDI inflows the host country. At the sector level, they studied different types of inward FDI to the United States and they suggested that the depreciation of the dollar in host country leads to an increase in the volume of FDI inflows the reason is due to increase in the wealth of investors and decrease in the cost of investment. The most important, they found a strong negative relationship between the level of the exchange rate and inward FDI in the industry of manufacturing. The Second hypothesis regarding the impact of changes in the level of exchange rates on FDI flows is known as the cost of labor hypothesis relative to the literature. The depreciation of the host currency encourages more FDI inflows due to the reduction in the cost of production day one day and catches more foreign investors. As study by18 (Cushman, 1988) found that the real depreciation of the currency of the primary host to promote an increase in FDI inflows, because it reduces production costs and wages in the host country. In contrast according to (Campa, 1993) the multinationals seeking profits in the local market and if they are optimistic about the future profitability, they increase their investment in this market. So, the model applications to appreciation currency countries home increase FDI inflows. Overall, the literature supports to the hypothesis that impairment of host countries ' currency increases the volume of FDI inflows. There is lot of literature available on the effect of exchange, but there is not an exact result that all studies agree with so that some of them suggested a positive relationship between exchange rate and foreign direct investment, others suggested a negative relationship, and still some have found no relationship. The most studies in the literature considered FDI flowing in developed countries rather than developing countries. So, the actual effect of the volatility of exchange rates on FDI is ambiguous within indeterminate and complex (Yuen and Geio, 2003)

The research about the relationship between the exchange rate, the volatility and macroeconomic variables, including foreign direct investment has a great importance in recent decades, especially after the collapse of Bretton Woods in 1971. After this collapse the majority of countries launched the flexible floating system / exchange rates and these countries face huge changes in the value of their foreign currency prices. Various studies show the existence of an association between the exchange rate, the floating exchange rates and foreign direct investment. (Tavlas, 1991) suggested that there is no adverse effect of the increase in exchange rate variability on the IDE subsystem floating rate. But a study by (Kogut and Chang, 1996) observed that the movement in the exchange rate is as a key determinant of foreign direct investment by Japanese electronics firms in the United States.

(Firoozi, 1997) searched that thetr exists a relationship between exchange rate volatility and FDI. According to (Crowley and Lee, 2003) there is the existence of a weak association between the volatility of exchange rates and investment, if the movements are comparatively low, but there is a strong relationship of excessive movement. As (Duiker and Gorg, 2009) concluded that the real exchange rate between two currencies is very important factor in determining FDI from Japan to China and the devaluation of the Chinese currency positively impacts the FDI inward in Japan during the sampling period. According to (Chong and Tan, 2008) there is the existence of the association between long-term volatility of exchange rates and macroeconomic factors in the Southeast Asian economies, but in there is a weak relationship. As (Jeon and Rhee, 2008) documented the presence of significant relationship between FDI inflows and real as well as changes in the exchange rates provided by Korea exchange rate. According to (Chowdhury and 
Wheeler, 2008) there are mixed results for association between exchange rate uncertainty and FDI. (Furceri and Borelli, 2008) suggested that the degree of openness of the country as a key factor to determine the effect of exchange rate volatility on FDI. As (Lee and Min, 2011) concluded that there are some other factors and found a nonlinear relationship between uncertainty and investment in Korea. (Nyarko and Amponsah, 2011) found that there is no significant relationship between the exchange rate regime for foreign direct investment in Ghana. (Vita and Abbot, 2008) in a research found that the volatility of the exchange rate negatively affects foreign direct investment in Pakistan. There are different studies on the impact of the volatility of exchange rates on FDI as with some showing positive association of the volatility of exchange rates for foreign direct according to (Fontagne and Revil, 2001) there is the negative effect of exchange rate volatility on FDI flows to developing countries. Also (Bleaney and Greenaway, 2001) found a negative impact of exchange rate volatility on investment. According to (Kiyota, 2004) there is an inverse relationship to the volatility of exchange rates on FDI, but the depreciation of the yen attract FDI. (Chen and Rau, 2006) in a research documented the significant effects of the exchange rate level and volatility have negative effect of exchange rate uncertainty on FDI enterprise. As (Schnabl, 2008) suggested that the role of exchange rate volatility, stability is related to the growth and there is a negative relationship between the volatility of the exchange rate and growth. As (Kyereboah and Tettey, 2008) searched that the volatility of exchange rates negatively affected the FDI inflows in Ghana. But according to (Nyarko and Barnor, 2011) there is the negative impact of exchange rate volatility on foreign direct investment flows in the UK. At the same time (Similarly and Erdal, 2002) found that the volatility of the exchange rate and inflation improbability negatively affect the foreign investment in the case of Nigeria, while according to (Crowley and Lee, 2003) the rate uncertainty change, negatively affects on FDI flows in all sectors in the United States.

As (Morrissey and Gorg, 2009) studied that volatility in exchange rate could adversely affect the FDI inflows. While there was an inverse relationship between the output of the devaluation and FDI. According to (Kandilov and Leblebicioglu, 2011) found that there is the existence of a strong negative and significant impact on the volatility of the real exchange rate on investment at the plant in Colombia.
While (Arratibel and Zdzienicka, 2011) documented that there is the existence of the negative and significant relationship of the volatility of exchange rates on FDI in member countries of the EU to Central and Eastern Europe. As (Cushman, 1988) documented that there is a positive association between exchange rate uncertainty and FDI in the United States.

As (Goldberg and Kolstad, 1995) documented that an increase in the production shares of installed capacity abroad in response to movements in the exchange rate. According to (Baek and Okawa, 2001) the appreciation of the yen against both the Asian and American currency results in an increase of foreign direct investment by Japan in the manufacturing sector and other sectors of Asia. (Gorg and Wakelin, 2002) recommended that investment or to direct or inside abroad is affected by the volatility of exchange rates in U.S. However, there exists a positive association in the case investments outside the United States with appreciation of the currency of the host country. While found negative association for foreign investment and appreciation in USD.

As (Gottschalk and Hall, 2008) concluded that the uncertainty of exchange rates in Japan is positively related to foreign direct investment in the countries of South Asia. While (Osinubi and Amaghionyeodiwe, 2009) proved that the depreciation of the domestic currency increases the real FDI in Nigeria. According to (Dhakal et al. 2010) the volatility of the exchange rate has a positive impact on FDI in the economies of selected East Asian sample. As (Takagi and Shi, 2011) searched that FDI increases with increased volatility of exchange rates, but decreased depreciation of the Japanese currency against the currency of the host country is Asia. While a study by (Nagubadi and Zhang, 2011) showed that the positive influence of the depreciation and volatility of the real exchange rate of the host country of the exchange rate on the bilateral FDI between the United States and Canada. Through this literature we assume the following hypotheses.

\section{H1. There is a positive relationship between exchange rate and FDI.}

\section{Theoretical Frame Work}

The following given theoretical frame work shows the relationship between exchange rate which is independent variable and dependent variable foreign direct investment.

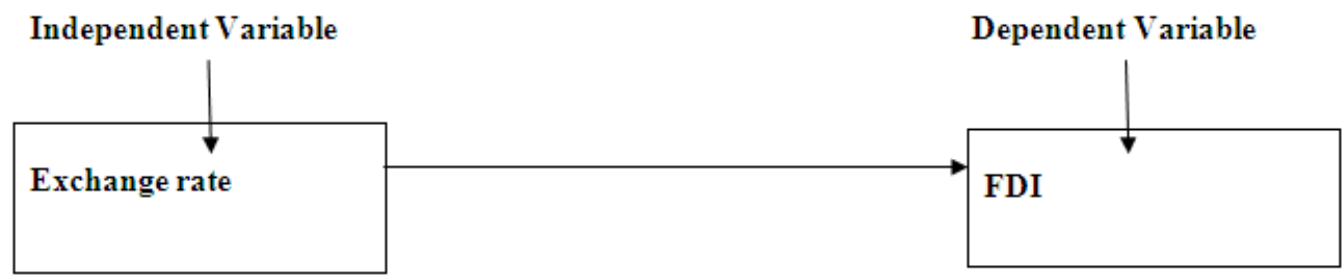

Figure 1. Proposed Model 


\section{Research Methodology}

This Study is based on secondary and time series data. The study is long term analysis, to check the impact of Exchange rate on FDI in Pakistan. For this purpose we collected the 32 years data of Exchange rate and FDI, for the period of to 1982 to 2013 for this research. The data was collected for our study from the website of State Bank of Pakistan. We apply the test of Correlation and regression in SPSS software to check the relationship between Exchange rate and FDI. In our research, the purpose of study would be descriptive because substantial year data is at hand and how this exchange rate impacts on FDI in the past. The type of investigation would be co relational study because we are interested in delineating the important variables associated with the problem. Hence, we are giving the detailed description of all the results and findings, we had from our research.

\section{Data Analysis}

\subsection{Correlation Analysis}

Correlation analysis shows the relationship among different variables. The correlation ranges from -1 to +1 . The significant relationship among different variables lies from 0.01 to 0.05 . The significance value more than 0.05 shows the insignificant relationship among the variables. The Mathematical signs like + , - show the direction of relation. The +1 value shows the perfect Positive relation and -1 value shows the perfect negative relationship. The zero value shows that there is no any relationship among the variables. Also it is noted that, by the definition, if any variable is correlated with itself has a correlation value of 1 . According to (Cooper and Schindler, 2011) correlation study identifies the association among two or more factors. Correlation research design has been selected to answer the relationship among research factors and questions.

Table 1. Correlations

\begin{tabular}{ccc}
\hline & Exchange Rate & $\begin{array}{c}\text { Foreign Direct } \\
\text { Investment }\end{array}$ \\
\hline Exchange Rate & 1 & \\
Pearson Correlation & & \\
Sig. (2-tailed) & 32 & \\
$\mathrm{~N}$ & & 1 \\
Foreign Direct & & \\
Investment & $0.379^{* *}$ & $0.033^{* *}$ \\
Pearson Correlation & 0.000 & 0.000 \\
Sig. (2-tailed) & 32 & 32 \\
$\mathrm{~N}$ &
\end{tabular}

**. Correlation is significant at the 0.01 level (2-tailed).

*. Correlation is significant at the 0.05 level (2-tailed).

The aim of this research was to know the relationship between independent variable Exchange rate and dependent variable Foreign Direct Investment. For this purpose correlation test was applied. The above mention correlation table shows the following result. The correlation value of Exchange rate is $0.379 * *$ at $\mathbf{p}=\mathbf{0 . 0 0 0}$ which shows positive significant relationship between independent variable Exchange rate and dependent variable Foreign Direct Investment with confidence interval of $99 \%$. This means that the data is $99 \%$ accurate only there is $0.01 \%$ chance.

Hypothesis 1: Exchange rate has positive effect on Foreign Direct Investment

As our hypothesis was Exchange rate has positive effect on Foreign Direct Investment, same supporting result has been found in this research. The above given correlation matrix shows that the innovation has positive correlation with value $\mathbf{0 . 3 7 9 * *}$, at $\mathrm{p}=0.000$ with confidence interval of $99.9 \%$ means only there is $1 \%$ chance of errors in results. This result shows the following interpretation "Exchange rate has Positive significant relationship with Foreign Direct Investment".

\subsection{Regression Analysis}

Regression analysis is used to show the accuracy and appropriateness of model and how much independent variable influence on the dependent variable in our study.

Table 2. Model Summary

\begin{tabular}{ccc}
\hline Model & $\mathrm{R}$ & R Square \\
\hline 1 & 0.379 & 0.679 \\
\hline
\end{tabular}

a. Predictors: (Constant), FDI

In this model summary the Capital " $R$ " shows the strength and weak relationship of independent variable Exchange rate and dependent variable Foreign Direct Investment. If the $\mathrm{R}$ square value is greater than $50 \%$ it shows the model is significant if less than $50 \%$ than it show the model is insignificant. In this study the R square value is 0.679 which is greater than $50 \%$ which shows that model is significant and is accurate. The dependent Exchange rate is affecting $67 \%$ to dependent variable FDI.

\subsection{ANOVA}

Table 3. ANOVA $^{b}$

\begin{tabular}{ccc}
\hline Model & F & Sig. \\
\hline Regression & 5.019 & 0.033 \\
\hline
\end{tabular}

Dependent Variable: FDI a. Predictors

In ANOVA mostly F-value is considered on significant level if significant value lies among 0.01 to 0.05 , then it is said the model is good, means "yes, the group of independent variables have the ability to reliably predict the dependent variable", otherwise the group of independent variables fail to show a significant relationship with the dependent variable, or in other words the group of independent 
variables does not reliably predict the dependent variable. Note that this test is used to test overall significance whether the group of independent variables when used together reliably predicts the dependent variable and does not use for single independent variable to predict the dependent variable.

As the above table 1.2 shows the ANOVA (analysis of variance) between independent variables Exchange with the dependent variable Foreign Direct Investment .In this research the $\mathrm{F}$-value $=5.019$ and significant value is 0.003 which shows the high level of significance and the group of independent variable Exchange Rate can be used to reliably predict the Foreign Direct Investment (the dependent variable). So this research proved that the model is very good and fit for research. The group of independent variable can predict the dependent variable.

\subsection{Discussion}

In this research, we find the relationship between Exchange rate and FDI in Pakistan. In correlation there is positive significant relationship between Exchange rate and FDI. It also satisfied the hypothesis of this research, as the hypothesis of this research was "Exchange rate has Positive effect on Foreign Direct Investment". The reason is that Pakistan is a developing country with rich natural resources and low labor cost, when the foreign company wants to invest in local currency of Pakistan, the company sees the currency exchange rate of Pakistan .when the exchange rate of Pakistan currency is high; simply it means that the company receives more currency for investment in Pakistan. So it has been proved in this research that exchange rate positively impacts on the Foreign Direct Investment. While in regression analysis $\mathrm{R}$ square value is more than $50 \%$ which shows that the research model is appropriate and exchange rate has $67 \%$ effect on FDI. In the ANOVA model $P$ value is significant because $0.033<0.05$, so this result also interprets that the independent variable Exchange Rate influences the dependent variable Foreign Direct Investment.

\section{Conclusions}

As Pakistan is a developing country of the world with rich natural resources and low labor cost could not achieve to attract FDI inflows to the country for years. Foreign Direct Investment inflows for Pakistan have shown very low growing pattern. The goal of the research was to investigate the impact of exchange rate volatility on FDI into Pakistan with very specific focus on annually data for the period between 1982-2013.

Finally, put the data into SPSS software and applied correlation and regression analysis tests the results suggested the strong evidence that exchange rate and its instability have significant effect on annually FDI inflows into Pakistan for the tested period of time. The results also indicated that exchange rate has strong positive correlation with FDI. The regression analysis showed that exchange rate has strong effect of $67.9 \%$ on FDI in Pakistan. So it is cncluised that the search model is appropriate the independent variable Exchange Rate can predict the dependent variable Foreign Direct Investment.

\section{Recommendation}

As the results mentioned earlier suggest that the policy makers in Pakistan must take into consideration both the instability in degree of exchange rate and existence. The policy makers must took the notice of the likely impact of the exchange stability on each macroeconomic variable in implementation of trade policies in Pakistan, so it is very clear that higher foreign direct investment and higher volumes of trades can be attracted.

\section{Future Research Direction}

The future researchers and related organizations may use these results in order to make managerial decisions which support their business requirements as well as the research requirements of the researchers. Making sure that the impact of exchange rate on FDI is $67.9 \%$ in Pakistan.

Originality: it is declared that this research is quit original. No any portion of this research has been copied.

\section{REFERENCES}

[1] Ullah, S., Hadier, S. \& Azim, P .(2012). Impact of exchange rate volatility on foreign direct investment. Pakistan economic and social review, 50, 121-138.

[2] Rehman, M., Arshad, Rehman, S. \& Ilyas, M. Studying determinants of FDI in Pakistan . Detreminants of FDI,

[3] Rehman, A. Adil, I. \& Anis, H. (2012). Exchange rate, j curve and debt burden of Pakistan Pakistan economic and social review, 50, 41-56.

[4] Javed, Z. \& Farooq, M. (2009). E conomic growth and exchange rate volatility in case of Pakistan. Pakistan journal of life and social sciences, 2, 112-118.

[5] Huchet-Bourdon, M. \& Korinek, J. (2011). To what extent do exchange rates and their volatility affect trade? OECD trade policy, 119.

[6] Mahmood, I. , Ehasnullah, M. \& Ahamd, H. (2011). Exchange rate volatility \& macroeconomic variables in Pakistan. Business management dynamics, 1, 11-22.

[7] Rehma n, M. , Mustafa, M. \& Rehman, M. (2004). Exchange rate and FDI. 1-7.

[8] Hassan, M.,Hassan, M, \& Mahmood, H. (2013). An empirical 
inquisition of the impact of exchange rate and economic growth on export performance of Pakistan. Middle-East journal of scientific research, 14, 288-299.

[9] Sattar, R., R. \& Rehman, H. (2012). Effectiveness of exchange rate in Pakistan. Pak j.comer. Soc.sci, 6, 83-96.

[10] Yuen-Ling, N., Wai-Mun, H \& Geio-Mie, T.(2003) Real exchange rate and trade balance relationship. International journal of business and management, 3 .

[11] Mustafa, K., \& Nishat, M. (2004). Volatility of exchange rate and export growth in Pakistan. The Pakistan development review, 43, 813-828.

[12] Kamal, A., (2005). Exchange rate instability and trade. Pakistan institute of development economics, 186.

[13] Payaslioglu, C. \& Polit, B. (2013). Impact of exchange rate uncertainty on FDI inward into Turkey. WEI international academic conference proceeding,

[14] Arratibel, O., Furceri, D., Martin, R., \& Zdzienicka, A. (2011). The effect of nominal exchange rate volatility on real macroeconomic performance in the CEE countries. Economic Systems , 35, 261-277.

[15] Froot, K. A. \& Stein, J.C. (1991). Exchange rates and foreign direct investment: An imperfect capital market approach. The Ouaterly Journal of Economics, 106, 1191-217.

[16] Cushman, D. (1985). Real exchange rate risk, expectations and the level of direct investment, The Review of Economics and Statistics, 67, 297-308.

[17] Campa, J. (1993). Entry of foreign firms in the United States under exchange rate uncertainty, The review of Economics and Statistics, 75, 614-22.

[18] Erdal, F. \& Tataoğlu, E. (2002). Locational determinants of foreign direct investment in an emerging market economy: Evidence from Turkey. Multinational Business review, Vol.10,No.1.

[19] Bailey, J.M. \& Tavlas, S.G. (1991). Exchange rate variability and direct investment. Annals of

[20] the AmericanAcademy of Political and Social Sciences, 516(1),106-116.Kogut, B., \& Chang,

[21] J.S. (1996). Platform investments and volatile exchange rates: Direct investments in the U.S. by Japanese electronic companies. The Review of Economics and Statistics, 78(2), 221-231.

[22] Firoozi, F. (1997). Multinational FDI and uncertainty: An exposition. Journal of Multinational Financial Management, $7,265-273$.

[23] Crowley, P. \& Lee, J. (2003). Exchange rate volatility and foreign investment: International evidence. The International Trade Journal, 17(3), 227-252.

[24] Chong, L-L. \& Tan, B-H. (2008). Exchange rate risk and macroeconomic fundamentals:

[25] Evidence from fourneighboring Southeast Asian economies. International Research Journal of Finance and Economics, 16, 88-95.

[26] Nyarko, A.P., Nketiah-Amponsah, E., \& Barnor, C. (2011). Effects of exchange rate regimes on FDI inflows in Ghana.
International Journal of Economics and Finance, 3(3), 277-286.

[27] Chowdhury, A. \& Wheeler, M. (2008). Does real exchange rate volatility affect foreign direct investment? Evidence from four developed economies. International Trade Journal, 22(2).

[28] Jeon, N.B. \& Rhee, S.S. (2008). The determinants of Korea's foreign direct investment from the United States, 1980-2001: An empirical investigation of firm-level data. Contemporary Economic Policy, 26(1),118-131.

[29] Benassy-Quere, A., Fontagne, L., \& LahrEche-Revil, A. (2001). Exchange-rate strategies in the competition for attracting foreign direct investment. Journal of the Japanese and International Economics, 15(2), 178-198.

[30] Bleaney, M. \& Greenaway, D. (2001). The impact of terms of trade and real exchange rate volatility on investment and growth in sub-saharan Africa. Journal of Development Economics, 65(2), 491-500.

[31] Kiyota, K. \& Urata, S. (2004). Exchange rate, exchange rate volatility and foreign direct investment. The World Economy, 27(10), 1501-1536.

[32] Schnabl, G. (2008). Exchange rate volatility and growth in small open economies at the EMU periphery. Economic Systems, 32, 70-91.

[33] Kyereboah-Coleman, A., \& Agyire-Tettey, F.K. (2008). Effect of exchange rate volatility on foreign direct investment in sub-saharan Africa: The case of Ghana. Journal of Risk Finance, 9(1), 52-70.

[34] Vita, D.G. \& Abbot, A. (2008). Do exchange rates have any impact upon UK inward foreign direct investment? Applied Economics, 39(20), 2553-2564.

[35] Kyereboah-Coleman, A. \& Agyire-Tettey, F.K. (2008). Effect of exchange rate volatility on foreign direct investment in sub-saharan Africa: The case of Ghana. Journal of Risk Finance, 9(1), 52-70.

[36] Nagubadi, V.R. \& Zhang, D. (2011). Bilateral foreign direct investment in forest industry between the U.S. and Canada. Forest Policy and Economics, 13, 338-344.

[37] Exchange rate movements and foreign direct investment (FDI): Japanese investment in Asia, 1987-2008. Japan and World Economy.

[38] Dhakal, D., Nag, R., Pradhan, G. \& Upadhyaya, P.K. (2010). Exchange rate volatility and foreign direct investment: Evidence from East Asian countries. International Business \& Economics Research Journal, 9(7), 121-128.

[39] Osinubi, T.S. \& Amaghionyeodiwe, L.A. (2009). Foreign direct investment and exchange rate volatility in Nigeria. International Journal of Applied Econometrics and Quantitative Studies, 6(2), 83-116.

[40] Gottschalk, S. \& Hall, S. (2008). Foreign direct investment and exchange rate uncertainty in South-East Asia. International Journal of Finance and Economics, 13, 349-359.

[41] Gorg, H. \& Wakelin, K. (2002). The impact of exchange rate volatility on US direct investment.The Manchester School, 70(3), 380-397. 
[42] Baek, I-M. \& Okawa, T. (2001). Foreign exchange rates and Japanese foreign direct investment in Asia. Journal of Economics and Business, 53, 69-84.

[43] Goldberg, S.L. \& Kolstad, D.C. (1995). Foreign direct investment, exchange rate variability and demand uncertainty. International Economic Review, 36(4), 855-873.

[44] Kandilov, T.I. \& Leblebiciogles, A. (2011). The impact of exchange rate volatility on plant-level investment: Evidence from Colombia. Journal of Development Economics, 94,
220-230.

[45] Udomkerdmongkol, M., Morrissey, O., \& Gorg, H. (2009). Exchange rates and outward foreign direct investment: US FDI in emerging economies. Review of Development Economics, 13(4),754-764.

[46] Ibrahim, M., Muhammad K. S., Sayed F. A. (2014). The Impact of Telecom Services Characteristics on Consumer for Use in Pakistan. Advances in Economics and Business 2(4): 172-179. 